\title{
Electroreflectance spectroscopy and scanning electron microscopy study of microrelief silicon wafers with various surface pretreatments
}

\author{
T. Ya. Gorbach, R. Yu. Holiney, I. M. Matiyuk, L. A. Matveeva, S. V. Svechnikov, E. F. Venger \\ Institute of Semiconductor Physics, NAS Ukraine, 45 prospekt Nauki, Kyiv, 252028, Ukraine \\ Phone: (38044) 265-83-17, Fax (38044) 265-83-42, E-mail: matveeva@semicond.kiev.ua
}

\begin{abstract}
The effect of various pretreatments on the performance of microrelief (textured) Si wafers was studied by the techniques of low-field electroreflectance spectroscopy, scanning electron microscopy, and electron diffraction. Four types of preliminary treatments were employed to prepare microrelief surfaces by anisotropic chemical etching: (i) cutting, (ii) cutting and mechanical polishing with $\mathrm{Al}_{2} \mathrm{O}_{3}$, (iii) cutting and chemical polishing with $\mathrm{HNO}_{3}: \mathrm{HF}$, and (iv) the standard industrial technique. Using the critical point energy $E_{g}$ at the central point in the Brillouin zone $\left(\Gamma_{25}^{\mathrm{V}}-\Gamma_{15}^{C}\right.$ transition) and the phenomenological parameter of broading $\Gamma$ to characterize the performance of the Si surface, it was found that anisotropic chemical etching performed after cutting produced the surface performance comparable to that of industrially fabricated wafers, but at a lower cost.
\end{abstract}

Keywords: silicon, microrelief wafer, cutting pretreatment, critical point energy, broading parameter.

Paper received 25.09.98; revised manuscript received 19.10.98; accepted for publication 28.10.98.

\section{Introduction}

The most obvious advantage of textured surfaces with a pyramid-shaped microrelief is their improved absorption profile. On the one hand, it is important for fabrication of solar cells [1]. On the other hand, morphological features of the microrelief (terraces, steps, kinks, etc.) act as surfaceactive species (surfactants) for film deposition. Good results (epitaxial growth, low-temperature deposition by various techniques, perfectly planar and abrupt interface, composition control, etc.) have been obtained despite the large mismatch in lattice and thermal parameters and the difference in crystal structure between the film and substrate [2-7]. It is well known that microrelief surfaces can be produced by anisotropic chemical etching (ACE) of crystalline silicon wafers $\{100\}$. The general problem of this fabrication step is the presence of untextured regions between pyramid bases. Currently, this problem is solved either by a pre- liminary removal of damage using isotropic etching in $\mathrm{NaOH}$ solution, or by adding a proper amount of isopropanol to the anisotropic etching solution. Our investigations had two objectives: (1) to improve the uniformity, and reproductivity of pyramid nucleation; 2) to lower the cost of wafer production. For these purposes, the performance of ACE microrelief wafers was compared depending on the pretreatment of $\mathrm{Si}$ wafers.

\section{Experimental details}

Four types of pretreatments of $\{100\}$ oriented $1 \Omega * \mathrm{~cm}$ B-doped p-Si wafers were used to prepare microrelief ACE surfaces: (i) cutting, (ii) cutting and mechanical polishing with $\mathrm{Al}_{2} \mathrm{O}_{3}$ (grain size 1-3 $\mu \mathrm{m}$ ), (iii) cutting and chemical polishing with $\mathrm{HNO}_{3}: \mathrm{HF}=3: 1$, with a removal of about $100 \mu \mathrm{m}$ thick Si layer, and (iv) the standard industrial pro- 


\section{T. Ya. Gorbach et al.: Electroreflectance spectroscopy...}
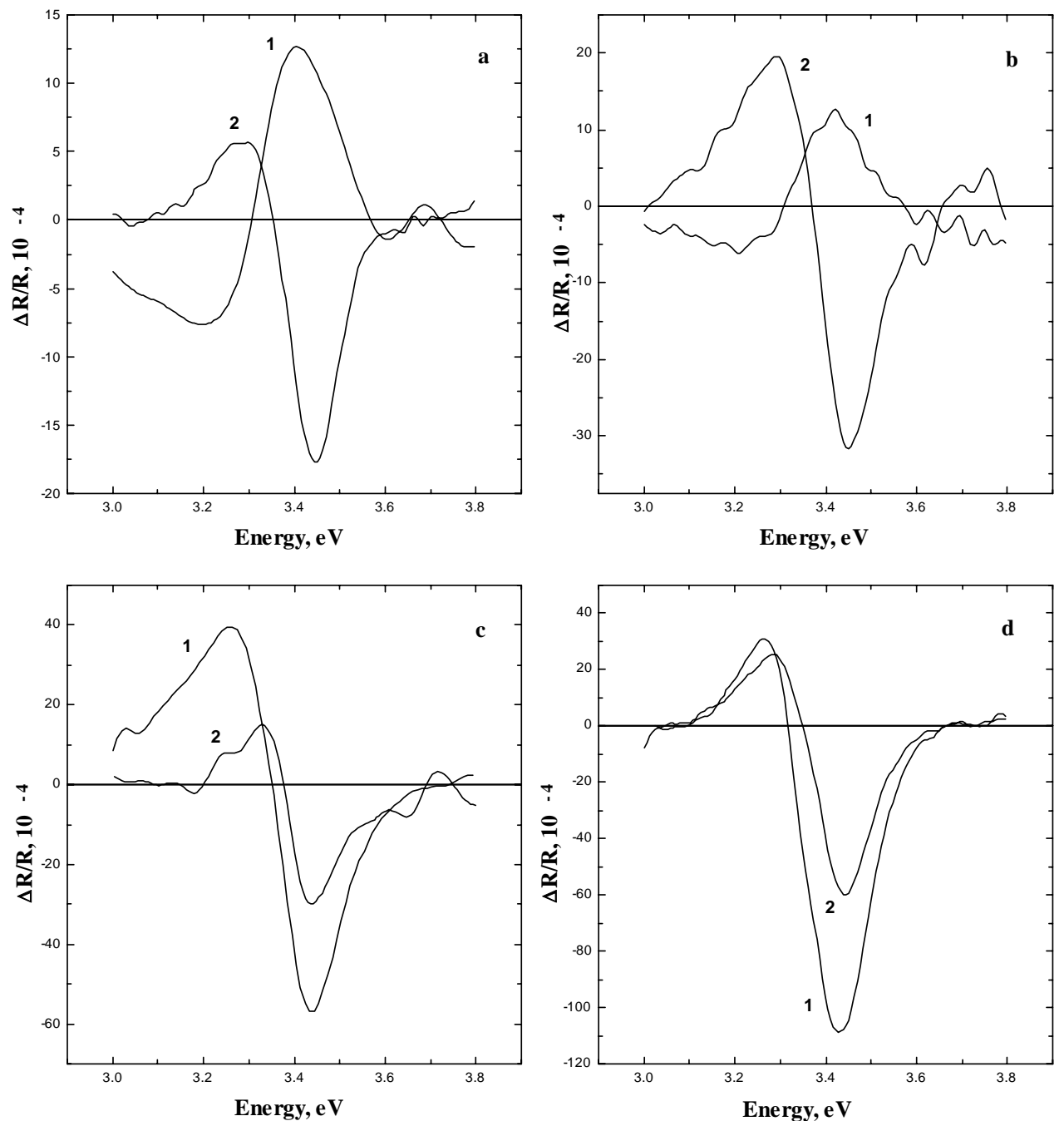

Fig. 1. ER spectra of Si surfaces subjected to various pretreatments: $a-$ cutting, $b$ - cutting and mechanical polishing, $c-c u t t i n g$ and chemical polishing, $\mathrm{d}$ - standard industrial fabrication. 1 - without ACE, 2 - after ACE.

cedure. ACE was carried out in $10 \% \mathrm{KOH}$ at $80^{\circ} \mathrm{C}$. Electroreflectance (ER) spectroscopy, scanning electron microscopy (SEM) and electronography (EG) were used to characterize the microrelief wafers and compare the results of pretreatments. ER measurements were made using a Si- $0.1 \mathrm{~N} \mathrm{KCI}$ system in the energy range from 3.0 to $3.8 \mathrm{eV}$ at room temperature in the low-field mode. The following indicators of surface perfection were used: (i) the critical point energy $\mathrm{E}_{\mathrm{g}}\left(\Gamma_{25}^{1 v}-\Gamma_{15}^{c}\right.$ transition), (ii) the value of the phenomenological broading parameter $\Gamma$, (iii) the value of the majority carriers mobility $\mu . E_{g}$ and $\Gamma$ were determined by analysis of the ER spectrum lineshape using the Aspnes three-point technique [8]. Mobility was calculated from the values of $\Gamma$ in the following form: $\mu \sim \mathrm{e} \hbar / \mathrm{m}^{*} \Gamma$, where $\mathrm{m}^{*}$ is the reduced effective mass [9]. SEM morphology analysis was performed with a Hitachi SEM-S-806 system. Crystallinity was studied with a EMR-100 electonograph .

\section{Results and discussion}

The effect of various pretreatments on $E, \Gamma$ and $\mu$ without and with ACE is shown in fig. 1 and summarized in Table 1.

ER measurements show that only two spectra - after cutting (fig. 1(a), curve 1) and after cutting and mechanical polishing (fig. 1(b), curve 1) have ER spectra with opposite signal polarity. This feature can be attributed to formation of a thin structureless Si layer near the surface with the type of carriers different from that in the wafer material (inversion or accumulation layer). Changes of the lineshapes and peak energies are observed for all spectra with the exception of those shown in fig. 1(d). Taking into account the estimates of the band-edge parameters and the carrier mobility values, it is shown that $\mathrm{Si}$ wafers fabricated by the standard industrial procedure have better surface perform- 
T. Ya. Gorbach et al.: Electroreflectance spectroscopy...

Table 1. Characteristic parameters of Si wafers.

\begin{tabular}{|c|c|c|c|c|c|c|}
\hline \multirow[t]{2}{*}{ Pretreatment } & \multicolumn{3}{|c|}{ Without ACE } & \multicolumn{3}{|c|}{ With ACE } \\
\hline & $\mathrm{E}_{\mathrm{gg} .}, \mathrm{eV}$ & $\Gamma, \mathbf{e V}$ & $\mu_{\mathrm{cm}}^{2} \mathrm{v}^{-1} \mathrm{~s}^{-1}$ & $\mathrm{E}_{\mathrm{g}, \mathrm{eV}}, \mathrm{eV}$ & $\Gamma, \mathrm{eV}$ & $\mu_{\mathrm{cm}}{ }^{2} \mathrm{v}^{-1} \mathrm{~s}^{-1}$ \\
\hline Cutting & 3.361 & 0.203 & 90 & 3.427 & 0.141 & 135 \\
\hline $\begin{array}{c}\text { Cutting and mechanical } \\
\text { polishing }\end{array}$ & 3.364 & 0.207 & 80 & 3.42 & 0.128 & 150 \\
\hline $\begin{array}{l}\text { Cutting and chemical } \\
\text { polishing }\end{array}$ & 3.34 & 0.184 & 100 & 3.41 & 0.105 & 270 \\
\hline $\begin{array}{c}\text { Standard industrial } \\
\text { fabricating }\end{array}$ & 3.412 & 0.146 & 125 & 3.411 & 0.145 & 128 \\
\hline
\end{tabular}

ance than those subjected to pretreatments. After ACE, the best surface performance is observed for wafers pre-treated by cutting and chemical polishing. Meanwhile, only a slight change in $E_{g}, \Gamma$, and $\mu$ was observed in the cases of microrelief surface preparation by other pretreatments, though there were significant differences in $E_{g}, \Gamma$ and $\mu$ on the initial surface. No difference in $E_{g}, \Gamma$, and $\mu$ exists when ACE is carried out for wafers fabricated by the standard industrial procedure. However, the performance of microrelief surfaces in the case of cutting pretreatment and the standard industrial procedure of fabrication is quite adequate, with the exception that the cost of the latter pretreatment is essentially higher because of the additional preparation steps.

SEM examination of the microrelief morphology of wafers subjected to various pretreatments demonstrates that in general there is no significant effect of pretreatment on the pyramid geometry and on the fine facet structure. That is why only the cutting pretreatment and the microrelief morphology after ACE of such surface have been examined in detail. According to microscopy observations (fig. 2(a)), the cutting surface has the morphology of random roughness of triangular or dendrit type with the height from 2 to $6 \mu \mathrm{m}$, and polycrystalline. After ACE of the surface prepared by cutting, the EG pattern shows a single-crystal structure with Kikuchi lines (fig. 2(f)). The SEM image (fig. 2(b)) demonstrates the presence of fairly homogeneous pyramid base sections separated in parallel to [110] or crossing by the angle of $90^{\circ}$ the grooves approximately 10-15 $\mu \mathrm{m}$ wide with quite a large nucleation density (fig. 2(c)). The grooved pyramids are about 2 to 3 times larger (the pyramid base side is about $10-15 \mu \mathrm{m}$ ) in comparison to the basic size. Fig. 2(d, e) confirms that there is an essential difference in the facet microstructure too. The facet of the basic pyramids clearly display the presence of steps with a nanostructure (fig. 2(d)) and the absence of nanoparticle-free zones. The facet of grooved pyramids is similar to that of pyramids formed on wafers subjected to other pretreatments, and does not have a branching picture (fig. 2(e)). The latter is probably not essential for fabrication of single-crystal Si solar cells, but may be critical when a microrelief wafer is used for thin-film solar cells, heteroepitaxy and other procedures of this kind. It should be noted that the SEM image (fig. 2(c)) shows that the pyramid size on the wafers subjected to cutting is larger than on those used for solar cells fabrication. To solve this problem, it is necessary to change the ACE conditions (for example, to lower the temperature).

\section{Conclusion}

Si surfaces of wafers treated and not treated by ACE were characterized by ER spectroscopy, SEM and EG. No significant effect was observed on the performance of microrelief surfaces subjected to cutting pretreatment or the standard industrial fabrication. A large potential is found for cost reduction of $\mathrm{Si}$ microrelief wafers by replacing a multistep long-time pretreatment of wafers with a one-step procedure. A new concept of using a saw-damaged surface (cutting pretreament) for effective ACE formation of a goodquality microrelief was demonstrated. 

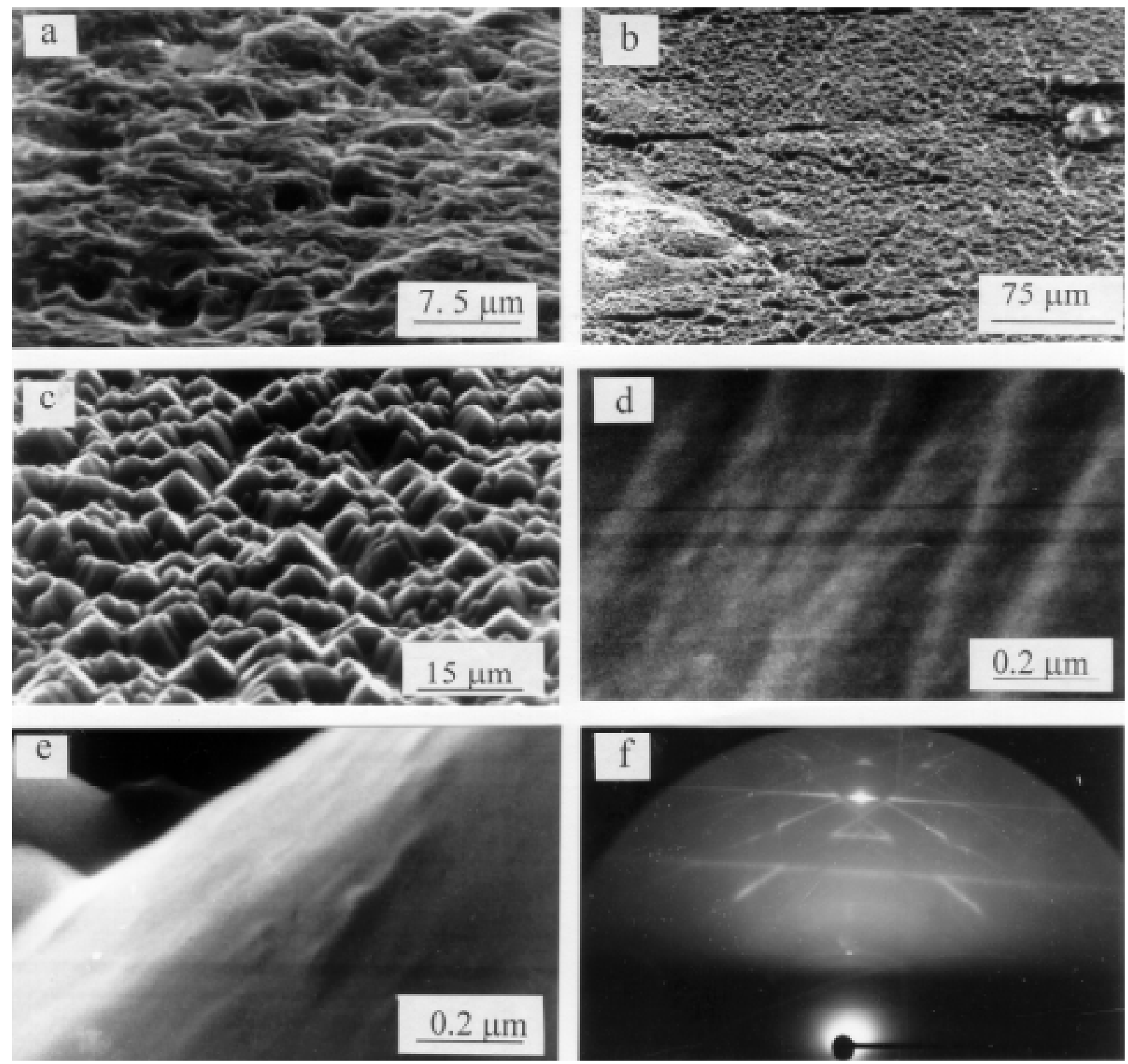

Fig. 2. SEM image (a-e) and EG pattern (f) of Si surface: a - cutting pretreatment; (b-e) - wafer after ACE; $b$ - general view of the surface; $c$ - surface fragment; $d, e$ - facet fragment; $f$ - EG pattern of the surface after ACE.

\section{References}

1. S.R. Wenham and M.A. Green, Progress in photovoltaics, 4, p. 3 (1996).

2. T.Ya. Gorbach, L.A. Matveeva, P.A. Sviridov and V.G. Chalaya, Electron. tech., ser. Mat., 4, p. 54 (1991).

3. T.Ya. Gorbach, M. Kuzma, E. Sheregii, P.S. Smertenko, S.V. Svechnikov and G. Wisz, Appl. Surf. Sci., 98, p. 881 (1996).

4. A.V. Vasin, L.A. Matveeva, T.Ya. Gorbach, A.G. Gontar and A.M. Kutsay, J. Chem. Vapor Depos., 6, p. 40 (1997).
5. T.Ya. Gorbach, L.A. Matveeva, S.V. Svechnikov, A.V. Vasin, E.F. Venger, Carbon, 36, 6, p. 513 (1998).

6. G. Wisz, E. Sheregii, M. Kuzma, P.S. Smertenko, S.V. Svechnikov, T.Ya. Gorbach, W. Maziarz, J. Morgiel, R. Ciach, Thin Solid Films, 33, p. 318 (1998).

7. T.Ya. Gorbach, R.Yu. Holiney, L.A. Matveeva, P.S. Smertenko, S.V. Svechnikov, E.F. Venger, R.Ciach and M. Faryna in Book of Abstracts EMRS-98 (Strassburg), D-16 (1998).

8. D.E. Aspnes, Surf. Sci., 37, p. 418 (1973).

9. A.R. Begishev, G.B. Galiev, V.V. Kapaev, V.G. Mokerov, Phys. and Techn. Poluprovodnikov, 16, p. 426 (1982). 


\title{
СПЕКРОСКОПІЯ ЕЛЕКТРОВІДИТТЯ ТА СКАНУЮЧА ЕЛЕКТРОННА МІКРОСКОПІЯ КРЕМНІЕВИХ МІКРОРЕЛЬЕФНИХ ПЛАСТИН 3 РІЗНИМИ ПОПЕРЕДНІМИ ОБРОБКАМИ ПОВЕРХНІ
}

\author{
Т. Я. Горбач, Р. Ю. Голіней, І. М. Матіюк, Л. О. Матвеєва, С. В. Свєчніков, Є. Ф. Венгер
}

\section{Інститут фізики напівпровідників НАН Украӥни}

Методами спектроскопії низькопольового електровідбиття, растрової електронної мікроскопії та електронографії досліджено вплив попередніх обробок поверхні кремнію (різка; різка та механічна поліровка; різка та хімічна поліровка; стандартна фабрична обробка) на досконалість анізотропно травлених мікрорельєфних пластин. Як критерій досконалості аналізуються енергія критичної точки $\mathrm{E}_{\mathrm{g}}$ в центрі зони Бріллюена (переходи $\Gamma_{25}^{\mathrm{V}}-\Gamma_{15}^{\mathrm{C}}$ ), феноменологічний параметр уширення $Г$, рухливість носіїв заряду, морфологічні особливості поверхні та кристалічна структура. Показана можливість використання попередньої обробки різкою для виготовлення достатньо досконалих анізотропно травлених мікрорельєфних пластин. При цьому очікується зменшення їх кошторису.

\section{СПРЕКТРОСКОПИЯ ЕЛЕКТРООТРАЖЕНИЯ И СКАНИРУЮЩАЯ ЭЛЕКТРОННАЯ МИКРОСКОПИЯ КРЕМНИЕВЫХ МИКРОРЕЛЬЕФНЫХ ПЛАСТИН С РАЗЛИЧНЫМИ ПРЕДВАРИТЕЛЬНЫМИ ОБРАБОТКАМИ ПОВЕРХНОСТИ}

\section{Т. Я. Горбач, Р. Ю. Голиней, И. Н. Матиюк, Л. А. Матвеева, С. В. Свечников, Е. Ф. Венгер}

Институт физики полупроводников НАН Украины

Методами спекроскопии низкополевого электроотражения, растровой электронной микроскопии и электронографии исследовано влияние предварительных обработок поверхности кремния (резка; резка и механическая полировка; резка и химическая полировка; стандартная фабричная обработка) на совершенство анизотропно травленных микрорельефных пластин. В качестве критерия совершенства анализируются энергия критической точки $\mathrm{E}_{\mathrm{g}}$ в центре зоны Бриллюэна (переходы $\left.\Gamma_{25}^{1 \mathrm{~V}}-\Gamma_{15}^{C}\right)$, феноменологический параметр уширения Г, подвижность носителей зӑряда, морфологические особенности поверхности и кристаллическая структура. Сделан вывод о возможности использования предварительной обработки резкой для получения достаточно совершенных анизотропно травленных микрорельефных кремниевых пластин. При этом ожидается снижение стоимости пластин. 